\title{
Induction of Glutathione Transferase in Insulin-Like Growth Factor Type I Receptor-Overexpressed Hepatoma Cells
}

\author{
Jeong Yong Lee, Chang Yeob Han, Jin Won Yang, Christopher Smith, Sang Kyum Kim, \\ Eva Y.-H. P. Lee, Sang Geon Kim, and Keon Wook Kang \\ BK21 Project Team, College of Pharmacy, Chosun University, Gwangju, South Korea (J.Y.L., C.Y.H., J.W.Y., K.W.K.); \\ Departments of Biological Chemistry/Developmental and Cell Biology, University of California at Irvine, Irvine, California \\ (E.Y.H.-P.L., C.S.); College of Pharmacy and Research Center for Transgenic Cloned Pigs, Chungnam National University, \\ South Korea (S.K.K.); and College of Pharmacy, Seoul National University, Seoul, South Korea (S.G.K.)
}

Received May 16, 2007; accepted July 5, 2007

\begin{abstract}
Insulin-like growth factor type I receptor (IGF-IR) is frequently overexpressed in human hepatocellular carcinoma cells (HCC), and this overexpression has been correlated with increased tumor growth. The protective response of $\mathrm{HCC}$ to reactive oxygen species (ROS) produced by chemotherapeutic agents is mediated with the induction of phase II detoxifying genes including glutathione transferase (GST). To understand the roles of IGF-IR overexpression in HCC in terms of its detoxifying effect on ROS and conferred resistance to chemotherapy, we analyzed whether IGF-IR overexpressions affect IGF-1-inducible GST expression. GST $\alpha$ was induced by exposure to IGF-1 in IGF-IR cells but not in cells expressing normal levels of IGF-IR. Furthermore, IGF-IR-overexpressed HCCs (IR-HCC) are more resistant to doxorubicin than control HCC cells, which was associated with the increased GST induction by IGF-1. Molecular analyses using GSTA2 promoter supported the in-
\end{abstract}

volvement of xenobiotic response element (XRE) in GST $\alpha$ induction. IGF-1 caused the nuclear translocation of CCAAT/ enhancer-binding protein $\beta(\mathrm{C} / \mathrm{EBP} \beta)$, which might be responsible for XRE activation. In addition, IGF-1 increased the activities of phosphatidylinositol 3-kinase (PI3-kinase) and extracellular signal-regulated kinase in IR-HCCs. Moreover, the inhibition of PI3-kinase completely abolished the nuclear translocation of C/EBP $\beta$ and the up-regulation of GST $\alpha$ protein in IR-HCC treated with IGF-1. However, specific inhibitors against extracellular signal-regulated kinase, c-Jun N-terminal kinase, or p38 kinase did not alter IGF-1-inducible GST $\alpha$ expression. These results provide evidence that one of the pathological consequences of IGF-IR overexpression in HCCs is the potentiation of GST $\alpha$ inducibility by IGF-1. Moreover, this potentiation of GST may be associated with decreased susceptibility to chemotherapeutic agents such as doxorubicin.
Hepatocellular carcinoma is the fifth most common malignant tumor worldwide. Hepatomas are likely to rise from normal cells through the accumulation of multiple genetic changes, which include the functional loss of tumor suppressor genes and the presence of activating oncogene mutations.

This work was financially supported by a Korean Research Foundation grant (KRF-2004-E00037).

J.Y.L., C.Y.H., and J.W.Y. contributed equally to this work.

Article, publication date, and citation information can be found at http://molpharm.aspetjournals.org.

doi:10.1124/mol.107.038174.
In addition to genetic changes in these genes, the expressions of growth factor receptors are up-regulated in hepatocellular carcinoma cells (HCC) (Yamaguchi et al., 1995; Scharf and Braulke, 2003). One of the growth factors predominantly implicated in hepatocarcinogenesis is insulin-like growth factor-1 (IGF-1). IGFs are synthesized and secreted by hepatocytes, and the interaction of IGF-1 with its receptor, IGF type I receptor (IGF-IR), plays a central role in the proliferation of a variety of cell types (Pietrzkowski et al., 1993; Scharf et al., 2001). Differentiated hepatocytes are not believed to be a major target for the actions of IGF-I, because only a few

\footnotetext{
ABBREVIATIONS: HCC, hepatocellular carcinoma cells; ARE, antioxidant response element; BCIP, 5-bromo-4-chloro-3-indoylphosphate; C/EBP, CCAAT/enhancer-binding protein; GST, glutathione transferase; IGF, insulin-like growth factor; IGF-IR, insulin-like growth factor type I receptor; IR-HCC, insulin-like growth factor type I receptor-overexpressed hepatocellular carcinoma cells; NBT, nitroblue tetrazolium; Nrf2, NF-E2-related factor 2; MAP, mitogen-activated protein; PBS, phosphate-buffered saline; PI3-kinase, phosphatidylinositol 3-kinase; ROS, reactive oxygen species; XRE, xenobiotic response element; ERK, extracellular signal-regulated kinase; JNK, c-Jun N-terminal kinase; MKK1, mitogenactivated protein kinase kinase 1; GFP, green fluorescent protein; MTT, 3-(4,5-dimethylthiazol-2-yl)-2,5-diphenyltetrazolium; TUNEL, terminal deoxynucleotidyl transferase dUTP nick-end labeling; DAPI, 4,6-diamidino-2-phenylindole; LY294002, 2-(4-morpholinyl)-8-phenyl-1(4H)-benzopyran-4-one hydrochloride; U0126, 1,4-diamino-2,3-dicyano-1,4-bis(methylthio)butadiene; SB203580, 4-(4-fluorophenyl)-2-(4-methylsulfinylphenyl)-5-(4-pyridyl) $1 \mathrm{H}$-imidazole; SP600125, anthra(1,9-cd)pyrazol-6(2H)-one 1,9-pyrazoloanthrone.
} 
IGF-I binding sites have been demonstrated on adult hepatocytes (Caro et al., 1988; McElduff et al., 1988). Whereas increased expression of IGF-IR in malignant hepatoma cells has been reported (Tsai et al., 1988), the physiological role of IGF-IR overexpression in HCC has not been completely clarified.

Reactive oxygen species (ROS) are persistently produced as a result of mitochondrial respiration during the uncontrolled growth of cancer cells. The capacity of cancer cells to maintain cellular functions during oxidative stress resides in the rapid induction of protective enzymes, which decrease oxidative stress. Protective adaptive response to electrophiles or ROS is mediated by enhancing the expression of phase II detoxifying genes. Glutathione transferases (GSTs) are a major group of phase II detoxification enzymes that display broad substrate specificity and provide protection against oxidative stress (Hayes and Pulford, 1995).

Based on the hypothesis that IGF-IR overexpression increases the inducibility of GST and that this induction is required for the efficient removal of ROS during uncontrolled cell growth or exposure to chemotherapeutic agents such as doxorubicin, we assessed the effect of IGF-1 on GST $\alpha$ expression in both H4IIE hepatoma cells and hepatoma cells overexpressing IGF-IR (IGF-IR-H4IIE cells). Here, we demonstrate for the first time that low concentrations of IGF-1 cause the induction of GST $\alpha$ in IGF-IR-overexpressing hepatoma cells and that the susceptibility of cells to ROS-generating doxorubicin is diminished by IGF-IR overexpression.

Our previous studies showed that Nrf2/antioxidant response element (ARE) and CCAAT/enhancer-binding protein $\beta(\mathrm{C} / \mathrm{EBP} \beta) / x e n o b i o t i c$ response element (XRE) pathways play essential roles in GST $\alpha$ induction and that this induction is mediated through a phosphatidylinositol 3-kinase (PI3-kinase) pathway (Kang et al., 2000, 2001, 2003a). Because the signaling pathways required for GST induction by growth factors have not been studied, our second objective was to determine whether the activation of PI3-kinase by IGF-1 is required for the $\mathrm{C} / \mathrm{EBP} \beta$ or Nrf2-mediated induction of GST $\alpha$. Herein, we demonstrate that the induction of GST $\alpha$ by IGF- 1 is controlled by PI3-kinase-dependent $\mathrm{C} / \mathrm{EBP} \beta$ activation in IGF-IR-overexpressing H4IIE cells.

\section{Materials and Methods}

Materials. Anti-GST $\alpha$ antibody was supplied by Detroit R\&D (Detroit, MI). Horseradish peroxidase-conjugated donkey anti-rabbit IgG, anti-goat IgG, and alkaline phosphatase-conjugated donkey anti-mouse IgG were purchased from Jackson Immunoresearch Laboratories (West Grove, PA). 5-Bromo-4-chloro-3-indoylphosphate (BCIP)/nitroblue tetrazolium (NBT) was from Invitrogen (Carlsbad, CA) . Anti-Nrf2, anti-IGF-IR $\beta$, anti-C/EBP $\beta$, anti-proliferating cell nuclear antigen, and anti-lamin B1 antibodies were from Santa Cruz Biotechnology (Santa Cruz, CA). Antibodies for phosphorylated Akt, Akt, phosphorylated extracellular signal-regulated kinase (ERK), ERK, phosphorylated c-Jun N-terminal kinase (JNK), JNK, phosphorylated p38 kinase, and p38 kinase antibodies were purchased from Cell Signaling Technology (Danvers, MA). Neutralizing monoclonal antibody against IGF-IR was supplied from Chemicon (Temecula, CA). Most of the reagents used for molecular studies were obtained from Sigma (St. Louis, MO). Mycp85 overexpression vector was provided by Dr. A. Toker (The Boston Biomedical Research Institute, Boston, MA). The mitogen-activated protein (MAP) kinase kinase 1 (MKK1) dominant-negative mutant was a gift from Dr. N. G. Ahn (Howard Hughes Medical Institute, University of Colo- rado, Boulder, CO). The JNK1 dominant-negative mutant (KmJNK1) and dominant-negative mutant of p38 kinase (dnp38K) were provided by Dr. N. Dhanasekaran (Fels Institute for Cancer Research and Molecular Biology, Temple University, Philadelphia, PA) and Dr. H. S. Choi (College of Pharmacy, Chosun University, Gwangju, Korea), respectively.

Cell Culture. H4IIE and HepG2 cells were obtained from the American Type Culture Collection (Manassas, VA) and Korea Cell Line Bank (Seoul, Korea), respectively. SK-Hep1 cells were kindly provided from Dr. K. Y. Lee (Chonnam National University, Gwangju, Korea). These three cell lines were maintained in Dulbecco's modified Eagle's medium containing $10 \%$ fetal calf serum, 100 $\mathrm{U} / \mathrm{ml}$ penicillin, and $100 \mu \mathrm{g} / \mathrm{ml}$ streptomycin at $37^{\circ} \mathrm{C}$ in a $5 \% \mathrm{CO}_{2}$ humidified atmosphere.

Construction of IGF-IR Retroviral Plasmid and the Infection of H4IIE Cells. IGF-IR was stably expressed in H4IIE cells using an MSCV-GFP retrovirus system provided by Dr. Scot W. Lowe at Cold Spring Harbor Laboratories (Cold Spring Harbor, NY). IGF-IR cDNA was subcloned into MSCV-GFP retroviral vector, and phoenix cells (a packaging cell line) were transfected with MSCVGFP (control) or MSCV-IGF-IR-GFP (IGF-IR-overexpressed) plasmid. Supernatants containing ecotropic replication-incompetent retroviruses were collected and then stored at $-80^{\circ} \mathrm{C}$ until required. H4IIE cells that were $30 \%$ confluent were multiply infected (eight times) with retrovirus particles. Intensities of infection were monitored by GFP-fluorescence, and Western blot analysis using a specific antibody.

Preparation of Nuclear Fractions. Nuclear extracts were prepared essentially as described by Schreiber et al. (1990). In brief, cells in dishes were washed with ice-cold phosphate-buffered saline (PBS), scraped, transferred to microtubes, and allowed to swell after adding $100 \mu \mathrm{l}$ of lysis buffer containing $10 \mathrm{mM}$ HEPES, $\mathrm{pH} 7.9,0.5 \%$ Nonidet P-40, $10 \mathrm{mM} \mathrm{KCl}, 0.1 \mathrm{mM}$ EDTA, $1 \mathrm{mM}$ dithiothreitol, and $0.5 \mathrm{mM}$ phenylmethylsulfonyl fluoride. Cell membranes were disrupted by vortexing, and lysates were incubated for $10 \mathrm{~min}$ on ice and centrifuged at $7200 \mathrm{~g}$ for $5 \mathrm{~min}$. Pellets containing crude nuclei were resuspended in $60 \mu \mathrm{l}$ of extraction buffer containing $20 \mathrm{mM}$ HEPES, pH 7.9, $400 \mathrm{mM} \mathrm{NaCl}, 1 \mathrm{mM}$ EDTA, $1 \mathrm{mM}$ dithiothreitol, and $1 \mathrm{mM}$ phenylmethylsulfonyl fluoride and then incubated for 30 $\mathrm{min}$ on ice. The samples were then centrifuged at 15,800g for $10 \mathrm{~min}$ to obtain supernatants containing nuclear extracts, which were stored at $-80^{\circ} \mathrm{C}$ until required.

Immunoblot Analysis. After washing H4IIE or IGF-IR-H4IIE cells with sterile PBS, they were lysed in buffer containing $20 \mathrm{mM}$ Tris-Cl, $\mathrm{pH}$ 7.5, 1\% Triton X-100, $137 \mathrm{mM}$ sodium chloride, 10\% glycerol, $2 \mathrm{mM}$ EDTA, $1 \mathrm{mM}$ sodium orthovanadate, $25 \mathrm{mM} \beta$-glycerophosphate, $2 \mathrm{mM}$ sodium pyrophosphate, $1 \mathrm{mM}$ phenylmethylsulfonyl fluoride, and $1 \mu \mathrm{g} / \mathrm{ml}$ leupeptin. Cell lysates were centrifuged at $10,000 \mathrm{~g}$ for $10 \mathrm{~min}$ to remove debris, and the supernatant proteins were fractionated using a 10\% separating gel. Fractionated proteins were then electrophoretically transferred to nitrocellulose paper, and proteins were immunoblotted with specific antibodies. The secondary antibodies used were horseradish peroxidase- or alkaline phosphatase-conjugated anti-IgG antibody. Nitrocellulose papers were developed using BCIP/NBT or an enhanced chemiluminescence system.

3-(4,5-Dimethylthiazol-2-yl)-2,5-diphenyl-tetrazolium Bromide Cell Viability Assay. To determine cell viabilities, cells were plated at $10^{4}$ cells/well in 96 -well plates. Viable adherent cells were stained with 3-(4,5-dimethylthiazol-2-yl)-2,5-diphenyl-tetrazolium bromide (MTT) $(2 \mathrm{mg} / \mathrm{ml})$ for $4 \mathrm{~h}$. Media were then removed, and the formazan crystals produced were dissolved by adding $200 \mu \mathrm{l}$ of dimethyl sulfoxide per well, and absorbance was assayed at $540 \mathrm{~nm}$. Cell viabilities are expressed as relative ratios to untreated control cells.

Terminal Deoxynucleotidyl Transferase dUTP Nick-End Labeling Assay. Terminal deoxynucleotidyl transferase dUTP nickend labeling (TUNEL) assays were performed using an in situ cell 
death detection kit (Roche Diagnostics GmbH, Mannheim, Germany). After 18-h incubation with either doxorubicin $(30 \mu \mathrm{M})$ or IGF-1 (30 ng/ml), GFP-H4IIE or IGF-IR-H4IIE cells were washed with PBS. Cells on slides were then fixed with $4 \%$ paraformaldehyde in PBS, $\mathrm{pH} 7.4$, for $1 \mathrm{~h}$ at room temperature and then permeabilized with $0.1 \%$ Triton $\mathrm{X}-100$ in $0.1 \%$ sodium citrate for 2 min on ice. They were then washed with $\mathrm{PBS}$, incubated for $60 \mathrm{~min}$ at $37^{\circ} \mathrm{C}$ after adding $50 \mu \mathrm{l}$ of $\mathrm{TdT}$ enzyme solution, incubated for $30 \mathrm{~min}$ at $37^{\circ} \mathrm{C}$ after adding $50 \mu \mathrm{l}$ of antifluorescent antibody (Fab fragment from sheep conjugated with alkaline phosphatase), and further incubated for $10 \mathrm{~min}$ in the presence of BCIP/NBT solution. Slides were then rinsed with phosphate-buffered saline, mounted under coverslips, and analyzed under an optical microscope.

Colony Formation Assay (Soft Agar Assay). The cells $(8 \times$ $10^{3} / \mathrm{ml}$ ) were maintained in $1 \mathrm{ml}$ of $0.3 \%$ basal medium Eagle's agar containing $10 \%$ fetal bovine serum and IGF-1 $(10 \mathrm{ng} / \mathrm{ml})$ with or without doxorubicin $(0.1 \mu \mathrm{M})$ at $37^{\circ} \mathrm{C}$ in a humidified incubator for 14 days. Cell colonies were counted using three different plates under microscope.

Determination of Caspase-3 Activity. Caspase-3 activity was assessed using a commercially available kit (CaspACE assay system; Promega, Madison, WI). In brief, caspase-3 activity was assayed with cell lysates $(50 \mu \mathrm{g})$ in the buffer solution, $\mathrm{pH} 7.5$, containing $0.1 \%$ 3-[(3-cholamidopropyl) dimethylammonio]-1-propane sulfonate, 100 mM HEPES, $10 \%$ sucrose, and $10 \mathrm{mM}$ dithiothreitol. Reaction was initiated by the addition of $100 \mu \mathrm{M}$ acetyl-Asp-Glu-Val-Asp-p-nitroanilide as a colorimetric substrate and continued for $4 \mathrm{~h}$ at $37^{\circ} \mathrm{C}$. Absorbance was measured at $405 \mathrm{~nm}$.

Construction of GSTA2 Promoter-Luciferase Constructs and Luciferase Assay. Firefly luciferase reporter gene construct pGL-1651 was generated by ligating pGL3-Basic vector (Promega) with the -1.65 promoter region of the GSTA2 gene, and the chimeric gene constructs, pGL-797, pGL-197 and pGL- $\Delta$ C/EBP ( -905 to -696 lacking reporter) were prepared using polymerase chain reactionamplified-deleted GSTA2 promoter regions (Kang et al., 2003a,b). To determine promoter activity, we used a dual-luciferase reporter assay system (Promega). In brief, cells $\left(3 \times 10^{5}\right.$ cells/well) were replated in 12-well plates overnight and transiently transfected with GSTA2 promoter-luciferase construct and pRL-SV plasmid (Renilla reniformis luciferase expression for normalization) (Promega) using Genejuice reagent (Novagen, Madison, WI). The cells were then exposed to IGF-1 for $18 \mathrm{~h}$, and firefly and $R$. reniformis luciferase activities in cell lysates were measured using a luminometer (TD-20; Turner Designs, Sunnyvale, CA). Relative luciferase activities were calculated by normalizing GSTA2 promoter-driven firefly luciferase activity versus $R$. reniformis luciferase.

Gel-Shift Analysis. A double-stranded C/EBP consensus oligonucleotide was used for gel-shift analysis after end-labeling the probe with $\left[\gamma^{3}{ }^{32} \mathrm{P}\right] \mathrm{ATP}$ using $\mathrm{T}_{4}$ polynucleotide kinase. The sequence of the C/EBP consensus oligonucleotide was 5'-TGCAGATTGCGCAATCTGCA- $3^{\prime}$. Reaction mixtures contained $4 \mu$ l of $5 \times$ binding buffer containing $20 \%$ glycerol, $5 \mathrm{mM} \mathrm{MgCl}_{2}, 250 \mathrm{mM} \mathrm{NaCl}, 2.5 \mathrm{mM}$ EDTA, $2.5 \mathrm{mM}$ dithiothreitol, $0.25 \mathrm{mg} / \mathrm{ml}$ poly(dI-dC), $50 \mathrm{mM}$ Tris$\mathrm{Cl}, \mathrm{pH} 7.5,10$ or $15 \mu \mathrm{g}$ of nuclear extracts, and sterile water to a total volume of $20 \mu \mathrm{l}$. The reaction mixtures were preincubated for $10 \mathrm{~min}$. DNA binding reactions were carried out at room temperature for 20 min after adding $1 \mu \mathrm{l}$ of probe $\left(10^{6} \mathrm{cpm}\right)$. Binding specificity was determined by using competition experiments, which were carried out by adding a 20 -fold excess of an unlabeled C/EBP, specific protein-1, or activator protein-1 oligonucleotide to reaction mixtures before the DNA binding reaction. For immunoinhibition assays, antibodies $(2 \mu \mathrm{g}$ of each) were added to reaction mixtures after an initial 20-min incubation and then incubated for a further $1 \mathrm{~h}$ at $25^{\circ} \mathrm{C}$. Samples were loaded onto $4 \%$ polyacrylamide gels at $100 \mathrm{~V}$, and removed gels were dried and autoradiographed.

Quantification of C/EBP $\beta$ Bound to XRE Region of GSTA2 Promoter. Biotin-labeled double-stranded oligonucleotide of XRE region of GSTA2 promoter was used for the quantification of $\mathrm{C} / \mathrm{EBP} \beta$ bound to XRE region. Reaction mixtures contained $10 \mu \mathrm{l}$ of $5 \times$ binding buffer containing $20 \%$ glycerol, $5 \mathrm{mM} \mathrm{MgCl}_{2}, 250 \mathrm{mM} \mathrm{NaCl}$, $2.5 \mathrm{mM}$ EDTA, $2.5 \mathrm{mM}$ dithiothreitol, $0.25 \mathrm{mg} / \mathrm{ml}$ poly(dI-dC), 50 $\mathrm{mM}$ Tris-Cl, $\mathrm{pH} 7.5,30 \mu \mathrm{g}$ of nuclear extracts, and sterile water to a total volume of $50 \mu \mathrm{l}$. DNA binding reactions were carried out at room temperature for $40 \mathrm{~min}$. The samples were additionally incubated with $100 \mu$ l of streptavidin-conjugated magnetic beads (MagnaBind-Streptavidin; Pierce, Rockford, IL) for $30 \mathrm{~min}$, and the DNA-bound beads were separated. After washing with PBS, the XRE-bound proteins were eluted with the buffer containing $0.1 \mathrm{M}$ glycine- $\mathrm{HCl}, \mathrm{pH} 2.8$ and fractionated using a 10\% separating gel. The fractionated proteins were then electrophoretically transferred to nitrocellulose paper and immunoblotted with $\mathrm{C} / \mathrm{EBP} \beta$ antibody.

Immunocytochemistry Analysis. IGF-IR-H4IIE cells were grown on Lab-TEK chamber slides (Nalge Nunc International, Rochester, NY) and incubated in serum-deprived medium for $48 \mathrm{~h}$. For immunostaining, the cells were fixed in $4 \%$ paraformaldehyde for $1 \mathrm{~h}$ and washed three times with PBS. After blocking in 5\% bovine serum in PBS for $1 \mathrm{~h}$ at room temperature, they were incubated for $1 \mathrm{~h}$ with anti-IGF-IR $\beta$, anti-C/EBP $\beta$, or anti-Nrf2 antibody (1:100) in PBS containing $0.5 \%$ bovine serum albumin, serially washed with PBS, and incubated with tetramethylrhodamine B isothiocyanateconjugated secondary antibody (1:100; Zymed Laboratories Inc., San Francisco, CA). Counterstaining with DAPI verified the locations and integrities of nuclei. Stained cells were washed and examined under a fluorescence microscope (Axiovert 200M; Carl Zeiss, Hamburg, Germany; supported from Chosun University, Gwangju. Korea).

Data Analysis. Scanning densitometry was performed using an Image Scan and Analysis System (Alpha-Innotech, San Leandro, CA) or FLA-7000 (Fujifilm, Japan). One-way analysis of variance procedures were used to assess significant differences between treatment groups. When treatment was found to have a significant effect, the Newman-Keuls test was used to compare multiple group means. Statistical significance was accepted at either $p<0.05$ or $p<0.01$.

\section{Results}

GST $\alpha$ Induction by IGF-1 in IGF-IR-Overexpressed Hepatoma Cells. Although differentiated hepatocytes expresses limited amounts of IGF-IR (McElduff et al., 1988), its expression level is up-regulated during hepatocarcinogenesis (Tsai et al., 1988). To mimic malignant hepatoma, we established H4IIE cells stably expressing IGF-IR (IGF-IR-H4IIE cells) by retroviral infection. As shown in Fig. 1A, immunocytochemistry using IGF-IR $\beta$-specific antibody showed that IGF-IR $\beta$ was mainly located in the transmembrane and cytoplasmic region and that the level of fluorescence was higher in IGF-IR-H4IIE cells than in GFP-overexpressed control (GFP-H4IIE) cells. We also determined IGF-IR expression levels by Western blot analysis in both cell types. Basal IGF-IR expression levels in IGF-IR-H4IIE cells were higher than those in GFP-H4IIE cells, and exposure of these cells to IGF-1 for $24 \mathrm{~h}$ caused the down-regulation of IGF-IR expression (Fig. 1B).

The hepatic expression of GST is affected by oxidative stress or chemotherapeutic agents (Kensler et al., 1987; Pinkus et al., 1996; Kim et al., 1997; Kang et al., 2001), and many types of cells produce small quantities of ROS in response to a variety of extracellular growth signals (Sundaresan et al., 1995; Bae et al., 1997); however, the role of growth factor(s) in GST expression has not been studied. Hence, we further examined the IGF-1-inducible expression of GST subtypes in both GFP-H4IIE and IGF-IR-H4IIE cells. GST $\alpha$ in 
A

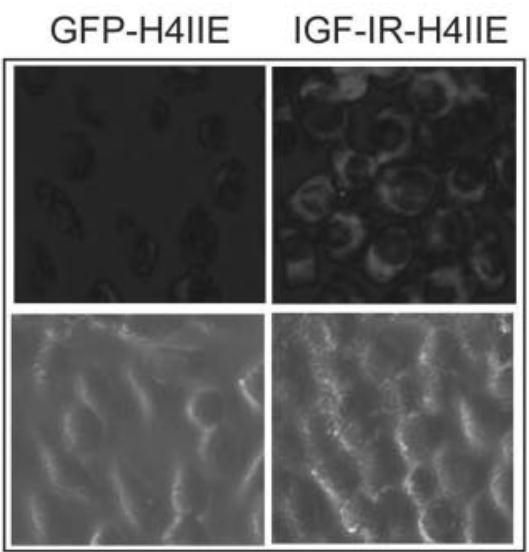

IGF-IR (TRITC staining)

Phase Contrast

B

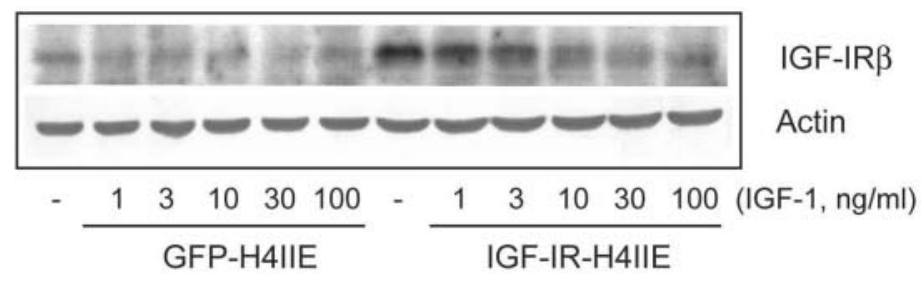

C
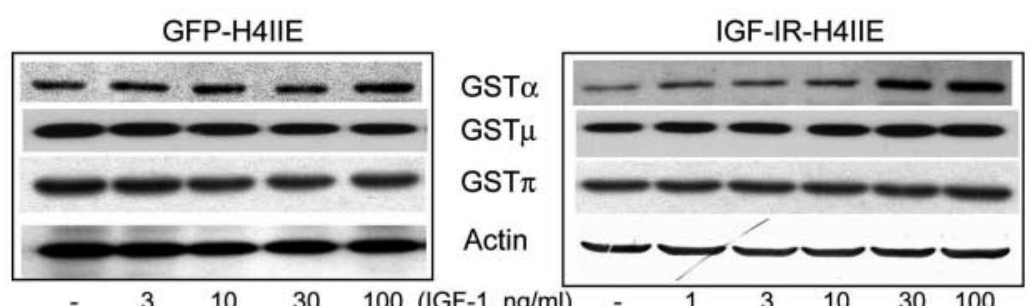

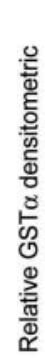
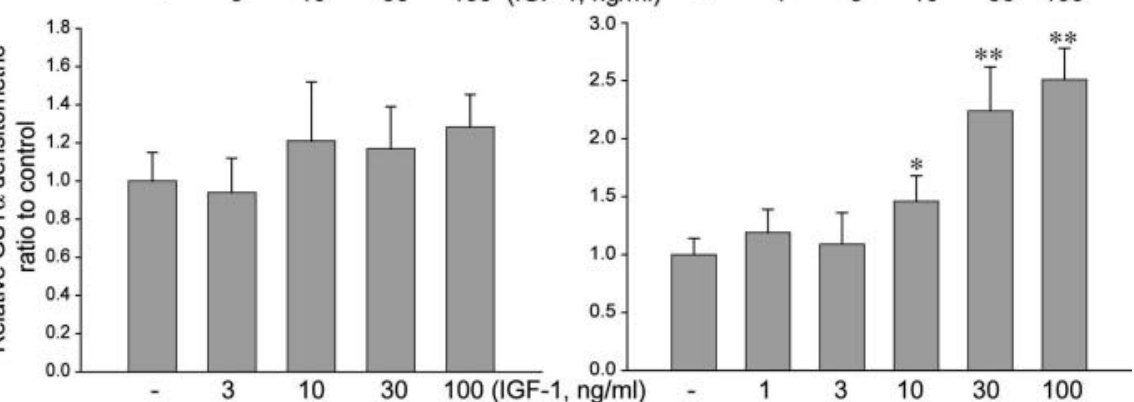

Fig. 1. GST $\alpha$ induction by IGF-1 in IGF-IR-overexpressing hepatoma cells. A, immunocytochemistry of IGF-IR. GFP-overexpressing H4IIE cells (GFP-H4IIE) and IGF-IR overexpressing H4IIE cells (IGF-IR-H4IIE) were stained with antibody highly specific for IGF-IR $\beta$. B, the expression of IGF-IR in GFP-H4IIE and IGF-H4IIE cells. Western blot analysis was performed using cell lysates (10 $\mu \mathrm{g} /$ lane) and anti-IGF-IR $\beta$ antibody. C, selective induction of GST $\alpha$ by IGF-1 in IGF-IR-overexpressing hepatoma cells. A representative immunoblot shows GST $\alpha$ protein in both GFP-H4IIE and IGF-IR-H4IIE cells incubated with IGF-1 (1$100 \mathrm{ng} / \mathrm{ml}$ ) for $18 \mathrm{~h}$. Each lane was loaded with 10 $\mu \mathrm{g}$ of protein. Equal protein loading was verified using actin as an internal standard. Relative changes in the GST $\alpha$ subunit were assessed by scanning densitometry. Data represent the means \pm S.D. of three separate experiments (significant versus the control: $*, p<0.05$; **, $p<$ 0.01; control level = 1). D, IGF-1-stimulated induction of GST $\alpha$ in SK-Hep1and HepG2 cells. SKHep1 cells were incubated with IGF-1 (10-100 $\mathrm{ng} / \mathrm{ml}$ ) for $18 \mathrm{~h}$. The immunoblots show IGF-IR $\beta$ (left, duplicated samples) and GST $\alpha$ proteins (right) in SK-Hep1 and HepG2 cells. Each lane was loaded with $10 \mu \mathrm{g}$ of protein.
$\mathrm{D}$
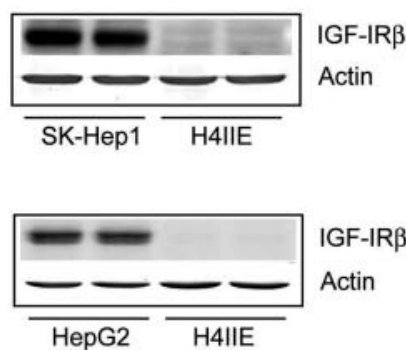

IGF-IR $\beta$ Actin

HepG2 H4IIE
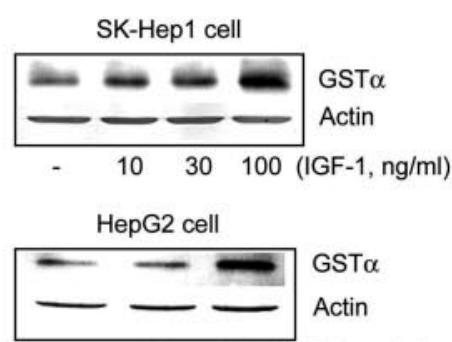

30100 (IGF-1, ng/ml) 
A

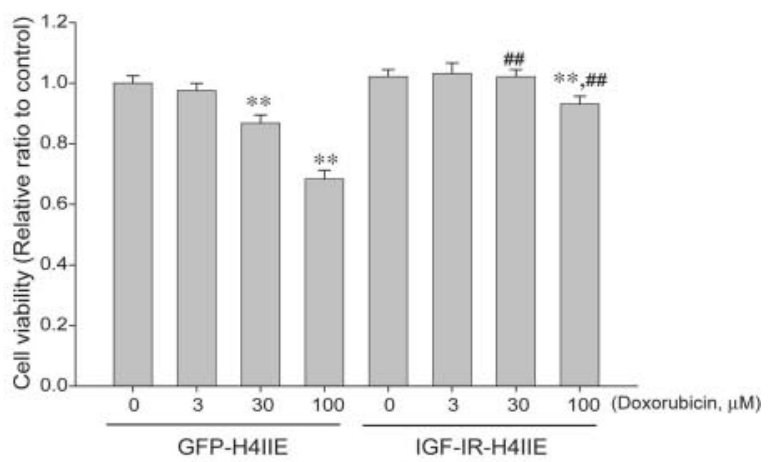

B

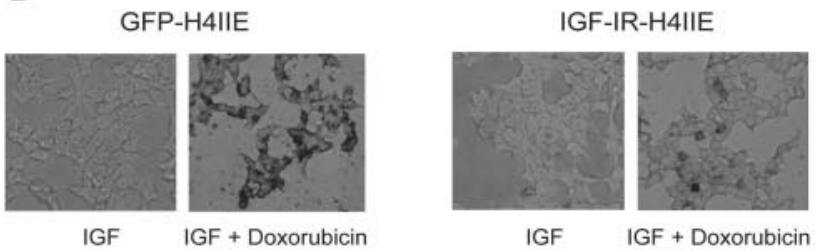

C

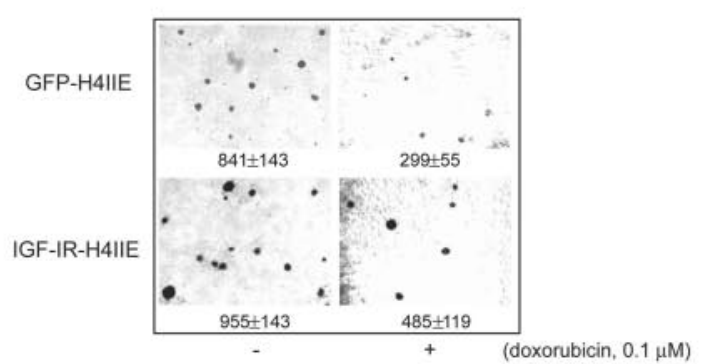

D

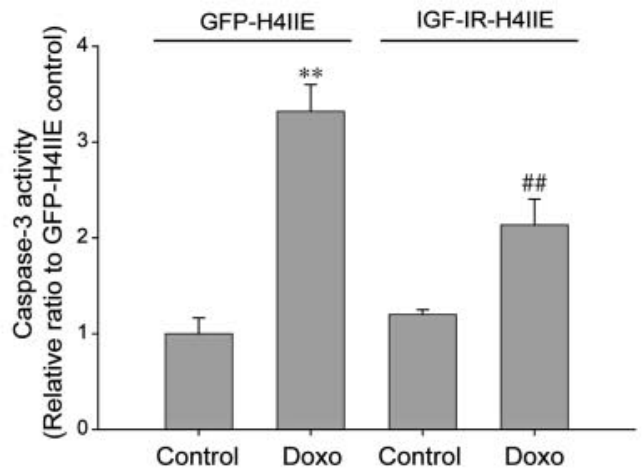

E

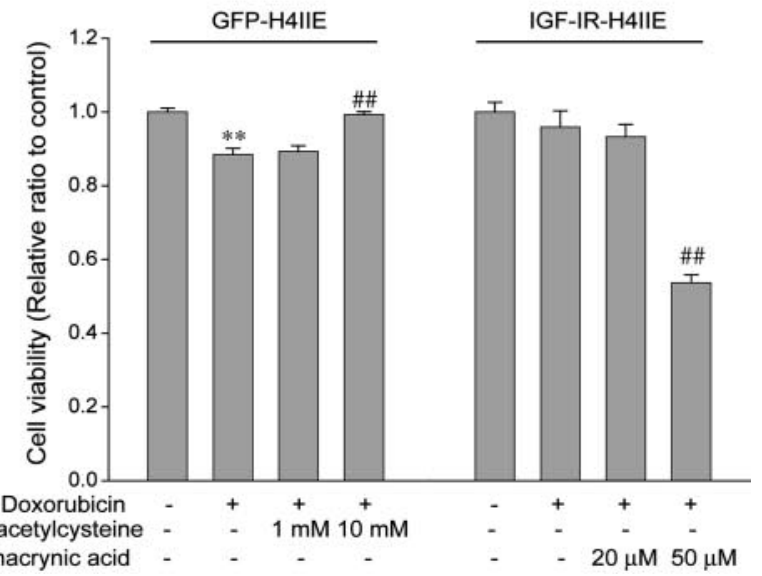

GFP-H4IIE cells was unaffected by IGF-1 at 3 to $100 \mathrm{ng} / \mathrm{ml}$ (Fig. 1C, left). In contrast, GST $\alpha$ was significantly induced by $10 \mathrm{ng} / \mathrm{ml} \mathrm{IGF-1} \mathrm{in} \mathrm{IGF-IR-H4IIE} \mathrm{cells,} \mathrm{and} \mathrm{the} \mathrm{extent} \mathrm{of}$ GST $\alpha$ induction was further enhanced by higher concentrations of IGF-1 (30 or $100 \mathrm{ng} / \mathrm{ml}$ ) (Fig. 1C, right). Other GST subunits such as GST $\mu$ and GST $\pi$ were unaffected by IGF-1 in both cell types (Fig. 1C). Moreover, supraphysiological concentration of IGF-1 $(1 \mu \mathrm{g} / \mathrm{ml})$ did not induce GST $\alpha$ in GFP-H4IIE cells (data not shown). These results suggest that IGF-1 signaling is coupled with the process of GST $\alpha$ induction and imply that physiological concentrations of IGF-1 induce GST $\alpha$ in IGF-IR-overexpressed hepatoma cells but not in GFP-overexpressed hepatoma cells.

Next, we also determined whether IGF-1 increased the expression of GST $\alpha$ in human hepatoma cell lines, SK-Hep1 and HepG2 cells. Basal IGF-IR levels in SK-Hep1 and HepG2 cells were higher than those in H4IIE cells, and $100 \mathrm{ng} / \mathrm{ml}$ IGF-1 induced GST $\alpha$ protein in both of the hepatoma cell lines (Fig. 1D).

The Induction of GST $\alpha$ in IGF-IR-Overexpressed Hepatoma Cells Was Associated with Chemoresistance against Doxorubicin. The cytotoxic effect of doxorubicin can be modulated by GST expression (Liu et al., 2001), and transfection with GST $\alpha$ cDNA protected HL-60 cells from doxorubicin-induced cytotoxicity (Cheng et al., 2001). Hence, we compared the doxorubicin-induced cytotoxicities in IGFIR-overexpressing H4IIE cells and GFP-overexpressing H4IIE cells (control cells). MTT assays showed that doxorubicin (30 or $100 \mu \mathrm{M}, 24$-h incubation) reduced cell viability in GFP-H4IIE control cells pretreated with IGF $(30 \mathrm{ng} / \mathrm{ml})$ for $18 \mathrm{~h}$ (Fig. 2A). In comparison to the control group, doxorubicin-induced cytotoxicity was significantly reduced in IGF-IRH4IIE cells pretreated with IGF-1 (Fig. 2A).

We also assessed doxorubicin-induced apoptosis in both cell types to establish the mechanistic basis of doxorubicin cytotoxicity. Representative TUNEL assay photographs showed that exposure of cells to doxorubicin for $24 \mathrm{~h}$ caused control cell apoptosis (Fig. 2B). TUNEL-positive indices were lower in IGF-IR-H4IIE cells than in GFP-H4IIE cells (Fig. 2B), which was consistent with MTT assay results. MTT assay represents the indices of chemical-induced cell death, whereas colony formation assay represents transformation or proliferation potential of cancer cells. We additionally

Fig. 2. A, cell viability after treating with doxorubicin. After treating GFP-H4IIE and IGF-IR-H4IIE cells with doxorubicin $(3-100 \mu \mathrm{M})$ for $24 \mathrm{~h}$, cell viabilities were determined using MTT assays. Data represent means \pm S.D. of eight separate samples (significant versus the control: **, $p<0.01$; significant versus cell viability in same concentration group of GFP-H4IIE cells, \#\#, $p<0.01$ ). B, representative photographs of TUNEL assays on cells cultured with or without $30 \mu \mathrm{M}$ doxorubicin for $18 \mathrm{~h} .30 \mathrm{ng} / \mathrm{ml}$ IGF-1 was pretreated $18 \mathrm{~h}$ before doxorubicin exposure. Results were confirmed by multiple experiments. Apoptosis (42\%) was observed at $30 \mu \mathrm{M}$ doxorubicin-treated GFP-H4IIE cells. C, colony formation assay. GFP-H4IIE and IGF-IR-H4IIE cells were incubated for 14 days with or without $0.1 \mu \mathrm{M}$ doxorubicin and $10 \mathrm{ng} / \mathrm{ml}$ IGF- 1 in soft agar plates. The numbers below each representative picture show average number \pm S.D. of colonies. D, caspase-3 activity. Caspase-3 activity was determined in cells incubated with or without $30 \mu \mathrm{M}$ doxorubicin for $24 \mathrm{~h}$. Data represent the means \pm S.D. of four separate experiments (significant versus the control: **, $p<0.01$; significant versus caspase- 3 activity in GFP-H4IIE cells: \#\#, $p<0.01$ ). E, left, effect of $N$-acetylcysteine ( 1 or $10 \mathrm{mM}$ ) on the cytotoxicity induced by $30 \mu \mathrm{M}$ doxorubicin in GFP-H4IIE cells. Right, effect of ethacrynic acid $(20$ or $50 \mu \mathrm{M})$ on the cytotoxicity induced by doxorubicin in IGF-IR-H4IIE cells. Data represent means \pm S.D. of eight separate samples (significant versus the control: **, $p<$ 0.01 ; significant versus doxorubicin-treated group: \#\#, $p<0.01$ ). 
performed colony formation assays using GFP-H4IIE and IGF-IR-H4IIE cells. IGF-treated IGF-IR-H4IIE cells are more resistant to the $0.1 \mu \mathrm{M}$ doxorubicin-mediated reduction of colony formation (Fig. 2C).

Caspase-3 plays an important role in the development of the morphological changes associated with apoptosis, such as DNA fragmentation and chromatin condensation. The apoptotic cell death caused by doxorubicin is also mediated by caspase-3 activation (Tsang et al., 2003). Thus, we investigated whether caspase-3 activation is inhibited in IGF-IRoverexpressing hepatoma cells. Exposure of GFP-H4IIE cells to $30 \mu \mathrm{M}$ doxorubicin for $24 \mathrm{~h}$ markedly activated caspase-3 (3.3-fold increase) (Fig. 2D), which is in contrast to that in IGF-IR-H4IIE control cells, in which doxorubicin-inducible caspase-3 activity was $51 \%$ reduced (Fig. $2 \mathrm{D}$ ).

Enhanced expression of GST $\alpha$ in IGF-IR-overexpressing hepatoma cells may be associated with reduced chemosensitivity. One plausible mechanism of doxorubicin-chemoresistance in cancer cells concerns the reduced formation of ROS by doxorubicin (Müller et al., 1998). Thus, we examined whether $N$-acetylcysteine, an antioxidant, blocked doxorubicin-induced cytotoxicity in GFP-H4IIE cells. MTT assay showed that apoptosis induced by doxorubicin was not reversed by $1 \mathrm{mM} N$-acetylcysteine but was completely reversed by $10 \mathrm{mM} N$-acetylcysteine (Fig. 2E). In addition, a minimal cytotoxicity by doxorubicin in IGF-IR-H4IIE cells was potentiated by a chemical inhibitor of GST, ethacrynic acid (Fig. 2E). The data suggest that increased GST $\alpha$ expression reduces cellular ROS formation by doxorubicin and that this might be related to chemoresistance to doxorubicin.

C/EBP/XRE-Dependent Transactivation of the GSTA2 Gene. The role of AREs in the inducible expression of phase II enzymes by antioxidants or radicals has been studied extensively (Kang et al., 2001, 2002a). Recently, we also showed that $\mathrm{C} / \mathrm{EBP} \beta$ activation is involved in chemopreventive agent-induced GST $\alpha$ gene expression via XRE element (Kang et al., 2003a,b). Given the roles of ARE or XRE in GST $\alpha$ expression, we performed reporter gene analyses using
A

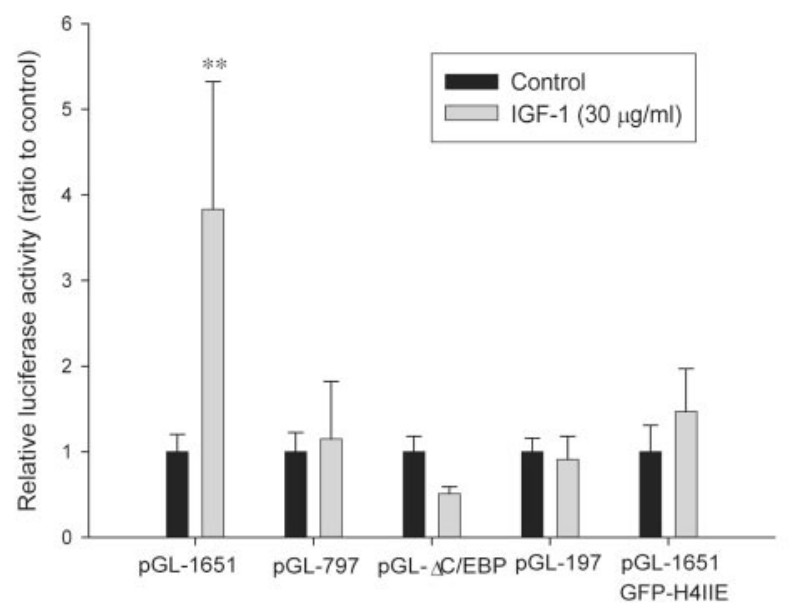

$\mathrm{B}$
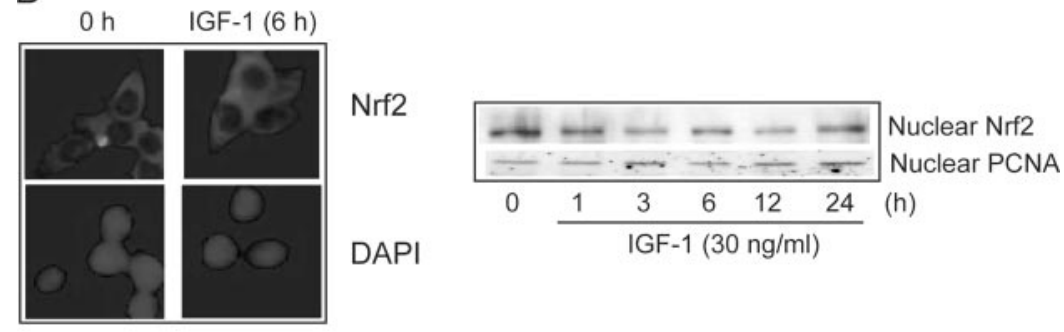

C

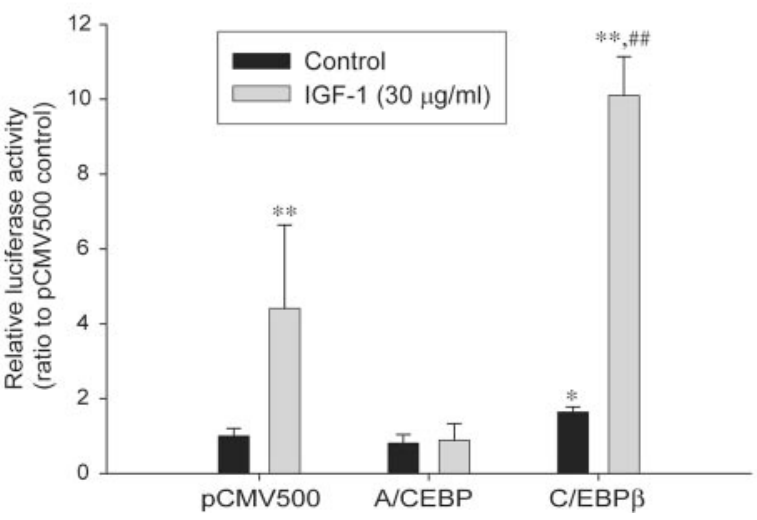

Fig. 3. Analysis of C/EBP-responsive element in the GSTA2 promoter. A, induction of luciferase activity by IGF-1 in IGF-IR-H4IIE cells transiently transfected with GSTA2 chimeric gene constructs pGL-1651 (containing both XRE and ARE elements), pGL-797 (containing ARE), pGL- $\Delta$ C/EBP (lacking C/EBP/XRE), or pGL-197 (minimal promoter). Dual luciferase reporter assays were performed on lysed cells cotransfected with GSTA2-luciferase gene constructs (firefly luciferase) and pRL-SV (R. reniformis luciferase) (ratio of 100:1) after exposure to IGF-1 (30 ng/ $\mathrm{ml}$ ) for $18 \mathrm{~h}$. Reporter gene activation was calculated as the relative ratio of firefly luciferase to $R$. reniformis luciferase activity. Data represent the means \pm S.D. of 4 to 10 separate samples (significant versus the control: $* *, p<0.01$ control level $=1$ ). B, left, immunocytochemistry and immunoblotting of Nrf2. IGF-IR-H4IIE cells were treated with $30 \mathrm{ng} / \mathrm{ml} \mathrm{IGF-1} \mathrm{for} 6 \mathrm{~h}$. Nrf2 was localized by immunostaining with anti-Nrf2 antibody. The same fields were counterstained with DAPI $(1 \mu \mathrm{g} / \mathrm{ml})$. B, right, levels of Nrf2 were assessed immunochemically in nuclear fractions of IGF-IR-H4IIE cells incubated with IGF-1 $(30 \mathrm{ng} / \mathrm{ml})$ for 1 to $24 \mathrm{~h}$. C, role of C/EBP in IGF-1-inducible pGL-1651 reporter gene activation. Cells were cotransfected with pGL-1651/pRL-SV40 (100:1) and AC/EBP (dominant-negative $\mathrm{C} / \mathrm{EBP}$ ) or $\mathrm{C} / \mathrm{EBP} \beta$-overexpressing vector in 1:1 ratio, and luciferase activities were measured $18 \mathrm{~h}$ after transfection. Luciferase activities are expressed as ratios of those of control cells transfected with pCMV500 (significant versus the control: $* *, p<0.01$; significant versus IGF-1 treated IGF-IR-H4IIE cells transfected with pCMV500: \#\#, $p<0.01$; control level $=1$ ). 
A
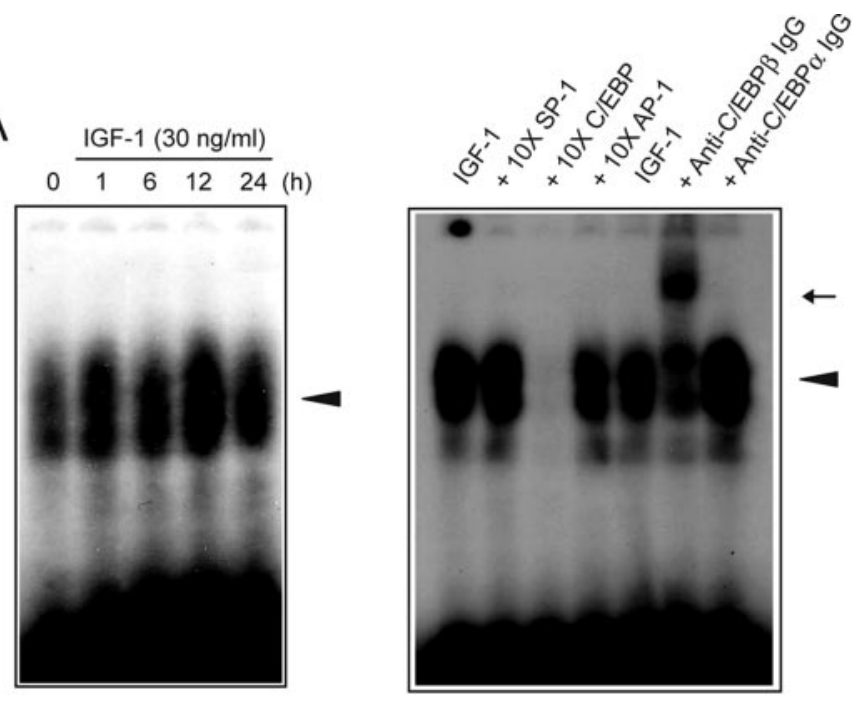

B

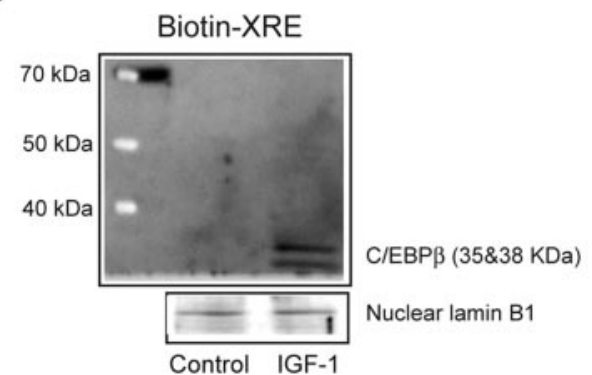

C

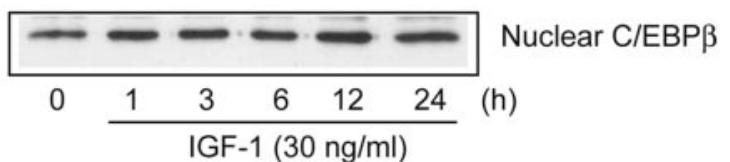

$0 \mathrm{~h}$

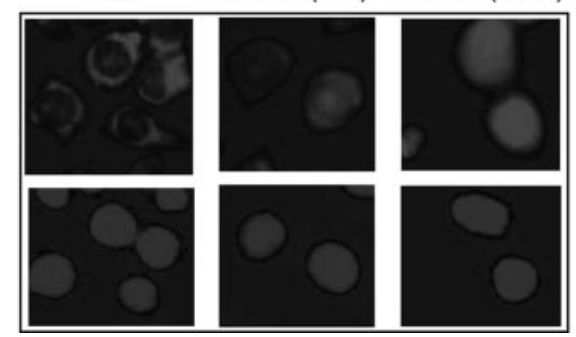

C/EBP $\beta$

DAPI

Fig. 4. Activation of $\mathrm{C} / \mathrm{EBP} \beta$ by IGF-1 in IGF-IR-overexpressing hepatoma cells. A, left, gel-shift analysis of the C/EBP transcription complex. Nuclear extracts were prepared from IGF-IR-H4IIE cells cultured in the

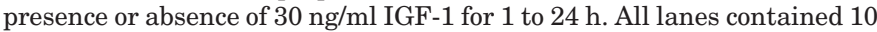
$\mu \mathrm{g}$ of nuclear extracts and $5 \mathrm{ng}$ of the labeled C/EBP consensus sequence. Right, competition assays with unlabeled C/EBP oligonucleotide or specific antibodies. Competition studies were carried out by adding a 10 -fold excess of unlabeled C/EBP, specific protein-1 (SP-1), activator protein-1 (AP-1) oligonucleotide, $\mathrm{C} / \mathrm{EBP} \beta$ antibody, or $\mathrm{C} / \mathrm{EBP} \alpha$ antibody to the nuclear extracts of cells treated with IGF- 1 for $6 \mathrm{~h}$. All lanes contained 15 $\mu \mathrm{g}$ of nuclear extracts and $5 \mathrm{ng}$ of the labeled C/EBP consensus sequence. DNA binding reactions were performed by gel-shift analysis. $\mathrm{B}$, determination of XRE-bound C/EBP $\beta$ using biotin-labeled XRE oligonucleotide and streptavidin-coated magnetic beads. Nuclear extracts were obtained from IGF-IR-H4IIE cells treated with or without $30 \mathrm{ng} / \mathrm{ml} \mathrm{IGF-1} \mathrm{for} 12 \mathrm{~h}$. $\mathrm{C}$, immunocytochemistry and immunoblotting of C/EBP $\beta$. IGF-IR-H4IIE

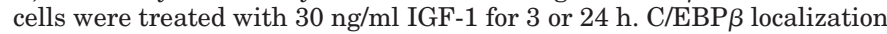
was detected by immunostaining with anti-C/EBP $\beta$ antibody. The same
pGL-1651, which contained the luciferase structural gene and a -1.65 kilobase GSTA2 promoter, and tried to identify the transcription factor(s) involved in GSTA2 gene transactivation by IGF-1. IGF-1 (30 ng/ml) caused a 3 -fold increase in the luciferase activity in IGF-IR-H4IIE cells transfected with pGL-1651 plasmid (Fig. 3A), which suggests that the induction of GST $\alpha$ by IGF-1 is mediated through the transcriptional activation of GSTA2 gene. Promoter deletion analyses were performed to clarify the binding site(s) required for this inducing activity of IGF-1. IGF-1-inducible luciferase activities were not observed in IGF-IR-H4IIE cells transfected with pGL-797 or pGL- $\Delta$ C/EBP, which contained ARE but not the XRE/CEBP binding region (Fig. 3A). Moreover, pGL-197, which lacked nucleotides -1651 to -198 of the GSTA2 gene flanking region, was not induced by IGF-1 (Fig. 3A). Nrf2 is believed to be an essential transcription factor for ARE activation (Huang et al., 2000; Kang et al., 2002b). Immunocytochemistry and Western blot analyses confirmed that IGF-1 (30 ng/ml) did not cause the nuclear translocation of Nrf2 or affect the nuclear level of Nrf2 (Fig. $3 \mathrm{~B})$. These results indicate that the XRE/C/EBP binding region, but not the ARE/Nrf2 binding region, in GSTA2 promoter is essentially required for the induction of GST $\alpha$ by IGF-1.

To further determine whether $\mathrm{C} / \mathrm{EBP}$ is associated with XRE activation by IGF-1, C/EBP-specific dominant-negative mutant (AC/EBP) (Kang et al., 2003a) was expressed in combination with pGL-1651 luciferase reporter in IGF-IR-H4IIE cells. pGL-1651 reporter activity was almost completely inhibited by dominant-negative mutant C/EBP expression, whereas transfection with pCMV500 (control vector) did not affect an increase in pGL-1651 reporter activity by IGF-1 (Fig. 3C). Moreover, overexpression of rat $\mathrm{C} / \mathrm{EBP} \beta$ (Lee and Kim, 2006) significantly potentiated pGL-1651 reporter activity by IGF-1 (Fig. 3C). These findings indicate that the $\mathrm{C} / \mathrm{EBP}$-binding sequence in the XRE region of the GSTA2 gene is responsible for GST $\alpha$ induction by IGF-1 in IGF-IRoverexpressed hepatoma cells.

Activation of C/EBP $\boldsymbol{\beta}$ by IGF-1. To test whether IGF-1 activates $\mathrm{C} / \mathrm{EBP}$, electrophoretic mobility shift assays were performed to determine C/EBP DNA binding activity using nuclear extracts prepared from IGF-IR-H4IIE cells treated with IGF-1. IGF-1 (30 ng/ml) resulted in a time-dependent increase in $\mathrm{C} / \mathrm{EBP}$ binding compared with untreated controls. C/EBP binding activity began to increase $1 \mathrm{~h}$ after treatment and was sustained for up to $24 \mathrm{~h}$ (Fig. 4A, left). Moreover, C/EBP binding activity was completely reversed by a 10 -fold excess of unlabeled C/EBP in nuclear extracts, which confirmed the specificity of protein binding to the C/EBP binding site (Fig. 4A, right). Competitive experiments using specific antibodies against $\mathrm{C} / \mathrm{EBP} \alpha$ or $\mathrm{C} / \mathrm{EBP} \beta$ showed that IGF-1-induced C/EBP DNA binding activity specifically depends on the $\mathrm{C} / \mathrm{EBP} \beta$ form. Moreover, anti-C/EBP $\beta$ antibody almost completely eliminated the band intensity and supershifted the retarded band (Fig. 4A, right). To quantify the XRE-bound $\mathrm{C} / \mathrm{EBP} \beta$, we also used biotin-labeled XRE oligonucleotide and streptavidin-coated magnetic beads. Al-

fields were counterstained with $1 \mu \mathrm{g} / \mathrm{ml}$ DAPI. For Western blot analysis of $\mathrm{C} / \mathrm{EBP} \beta$ in nuclear fractions, nuclear extracts were obtained from IGF-IR-H4IIE cells treated with IGF-1 for 1 to $24 \mathrm{~h}$, and C/EBP $\beta$ was detected immunochemically with specific antibody. 
though $\mathrm{C} / \mathrm{EBP} \beta$ bound to XRE oligonucleotide was minimal in control sample, IGF-1 treatment caused an increase in XRE-bound C/EBP $\beta$ (Fig. 4B). Nuclear lamin B1 levels were determined as loading controls.

Because $\mathrm{C} / \mathrm{EBP} \beta$ is mainly located in the cytoplasmic fraction and is translocated to the nucleus upon activation, we determined the nuclear levels of $\mathrm{C} / \mathrm{EBP} \beta$ by subcellular fractionation and immunoblotting. Nuclear levels of $\mathrm{C} / \mathrm{EBP} \beta$ were increased from 1 to $24 \mathrm{~h}$ after exposing cells to $30 \mathrm{ng} / \mathrm{ml}$ IGF-1, which was consistent with the gel-shift assay results (Fig. 4C). To verify this result, we also carried out immunocytochemical analysis using $\mathrm{C} / \mathrm{EBP} \beta$-specific antibody. $\mathrm{C} / \mathrm{EBP} \beta$ was located predominantly in the cytoplasm of control cells (Fig. 4C), whereas it had a nuclear localization in cells treated with $30 \mathrm{ng} / \mathrm{ml}$ IGF-1 ( $3 \mathrm{~h}$ ), which suggested that $\mathrm{C} / \mathrm{EBP} \beta$ might move into the nucleus. At later time points (i.e., $24 \mathrm{~h}$ after IGF-1 exposure), $\mathrm{C} / \mathrm{EBP} \beta$ was observed to be predominantly distributed in the nucleus (Fig. 4C).

Role of PI3-Kinase in GST $\alpha$ Induction by IGF-1. Previous studies have shown that PI3-kinase and its downstream kinases (e.g., Akt and p70S6 kinase) are involved in cellular responses to growth factor(s) (Dupont and Le Roith, 2001; Cho and Kim, 2003). Moreover, a series of our studies also demonstrated that PI3-kinase plays a key role in the induction of phase II detoxifying genes (Kang et al., 2000,
2001, 2003a). To estimate whether IGF-1 activates PI3-kinase in IGF-IR-H4IIE cells, we determined the extent of the phosphorylation of Akt, a downstream kinase of PI3-kinase. IGF-1 (30 ng/ml) transiently (5-10 min) increased phosphorylated Akt levels in IGF-IR-H4IIE cells (Fig. 5A). However, IGF-1 failed to activate PI3-kinase in GFP-H4IIE cells (Fig. $5 \mathrm{~A})$. We then assessed the role of PI3-kinase in $\mathrm{C} / \mathrm{EBP} \beta$ mediated GST $\alpha$ induction in IGF-IR-overexpressing cells. Pretreatment of these cells with LY294002 (20 $\mu \mathrm{M})$, a specific inhibitor of PI3-kinase, completely blocked the induction of GST $\alpha$ and the nuclear accumulation of C/EBP $\beta$ in IGF-IRH4IIE cells by IGF-1 (Fig. 5B). To confirm the role of PI3kinase, IGF-1-inducible pGL-1651 reporter activity was monitored in IGF-IR-H4IIE cells overexpressing the mycp85 functions as a kind of dominant-negative. Mycp85 overexpression also inhibited an increase in pGL-1651 reporter activity by IGF-1 (Fig. 5C). These results raised the possibility that the PI3-kinase pathway controls $\mathrm{C} / \mathrm{EBP} \beta$ and $\mathrm{C} / \mathrm{EBP} \beta$-dependent GST $\alpha$ gene expression.

Previously, it was proposed that ERK1/2 and p38 kinase might be associated with the induction of quinone reductase and $\gamma$-glutamylcysteine synthetase, respectively (Yu et al., 1999; Zipper and Mulcahy, 2000). To study whether MAP kinase pathways are also stimulated by IGF-1 in IGF-IRH4IIE cells, we measured the activity of each MAP kinase as
A

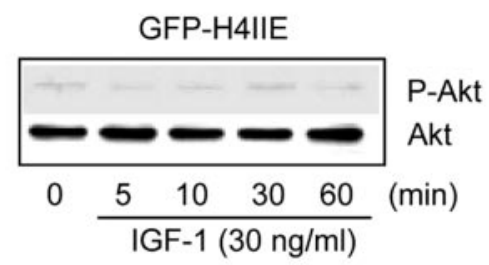

B

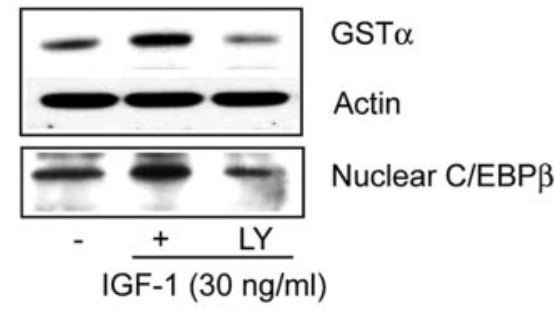

C

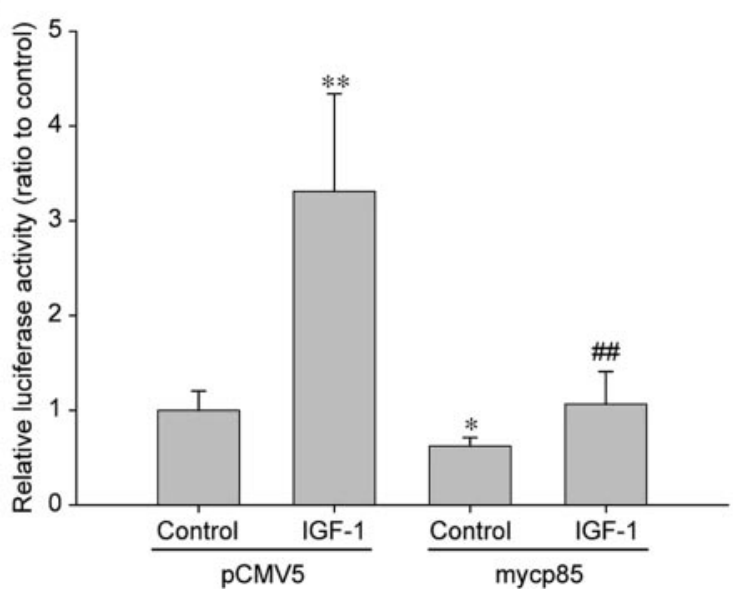

Fig. 5. PI3-kinase-dependent GST $\alpha$ induction by IGF-1 in IGF-IR overexpressing hepatoma cells. A, IGF-1-inducible PI3-kinase activation. PI3-kinase activity was assessed using phosphospecific Akt antibody. IGF-IR-H4IIE cells were treated with IGF-1 $(30 \mathrm{ng} / \mathrm{ml})$ for $5 \mathrm{~min}$ to $1 \mathrm{~h}$. B, effects of PI3-kinase inhibitor on $\mathrm{C} / \mathrm{EBP} \beta$ activation and GST $\alpha$ protein induction by IGF-1. The levels of GST $\alpha(18 \mathrm{~h})$ and $\mathrm{C} / \mathrm{EBP} \beta(6 \mathrm{~h})$ were determined by Western blot analysis in IGF-IR-H4IIE cells cultured with 30 $\mathrm{ng} / \mathrm{ml}$ IGF- 1 in the presence or absence of $20 \mu \mathrm{M}$ LY294002 (LY). C, effect of mycp85 overexpression on pGL-1651 reporter activity. pGL-1651 reporter activity change by IGF-1 ( $30 \mathrm{ng} / \mathrm{ml})$ was measured in IGF-IR-H4IIE cells transiently transfected with 1 $\mu \mathrm{g}$ of mycp 85 or $1 \mu \mathrm{g}$ of pCMV5. 
a function of time after IGF-1 treatment. The level of active phosphorylated ERK1/2 was increased at 5 to 30 min after IGF-1 treatment and peaked at $10 \mathrm{~min}$ (Fig. 6A). However, the phosphorylation intensities of JNK or p38 kinase were only slightly affected in IGF-IR-H4IIE cells stimulated by 30 $\mathrm{ng} / \mathrm{ml}$ IGF-1 from $5 \mathrm{~min}$ to $3 \mathrm{~h}$ (Fig. 6A). To investigate whether blockade of the MAP kinase cascade led to a change in the expression of GST $\alpha$, we determined pGL-1651 reporter activity in IGF-IR-H4IIE cells transfected with dominantnegative mutants of MKK1 (ERK inhibition), JNK, and p38 kinase. Transfection of each dominant-negative mutant did not alter the IGF-1-mediated increase in pGL-1651 reporter

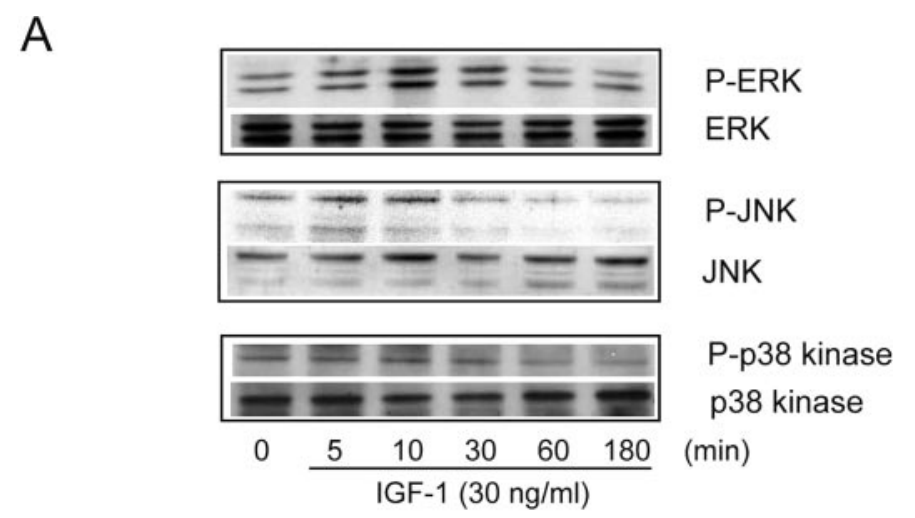

B

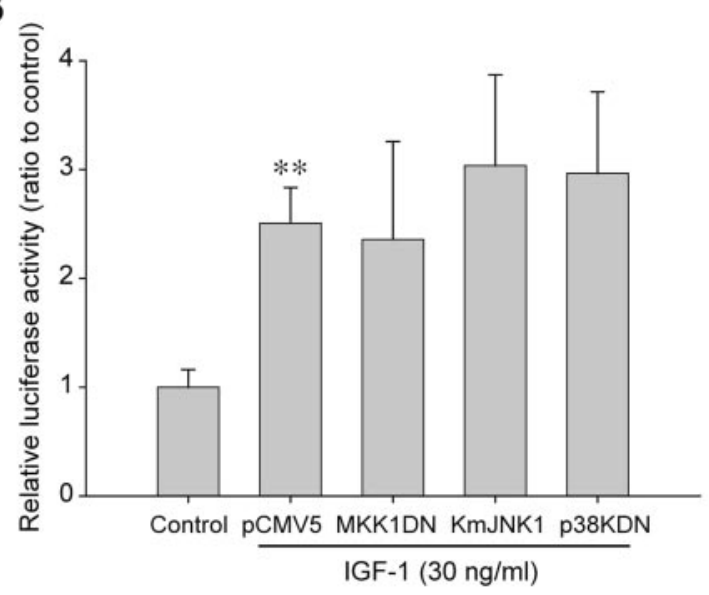

C

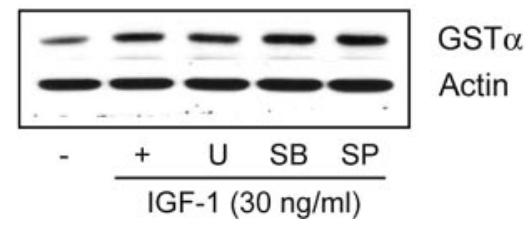

Fig. 6. Effects of MAP kinase inhibition on GST $\alpha$ up-regulation by IGF-1 in IGF-IR-overexpressing hepatoma cells. A, the effects of IGF-1 (30 $\mathrm{ng} / \mathrm{ml}$ ) on MAP kinase phosphorylation. The activations of ERK, p38 kinase, and JNK were assessed by immunoblotting the phosphorylated forms of these MAP kinases. B, the effects of dominant-negative mutants of MKK1 (MKK1DN), JNK (KmJNK1), and p38 kinase (p38KDN) on pGL-1651 reporter activity. pGL-1651 reporter activity changed by IGF-1 $(30 \mathrm{ng} / \mathrm{ml})$ was measured in IGF-IR-H4IIE cells transiently transfected with $1 \mu \mathrm{g}$ of each dominant-negative mutant or $1 \mu \mathrm{g}$ of pCMV5. C, the effects of ERK, p38 kinase, and JNK inhibitors on GST $\alpha$ expression. IGF-IR-H4IIE cells were treated with $30 \mathrm{ng} / \mathrm{ml} \mathrm{IGF-1} \mathrm{for} 18 \mathrm{~h}$ with or without specific inhibitors (10 $\mu \mathrm{M}$ U0126, U; $10 \mu \mathrm{M}$ SB203580, SB; 10 $\mu \mathrm{M}$ SP600215, SP). activity (Fig. 6B). We also assessed whether the GST $\alpha$ expression is changed by MAP kinase inhibitors. IGF-IR IGFIR-H4IIE cells were preincubated with specific MAP kinase inhibitors for $30 \mathrm{~min}$ and then exposed to $30 \mathrm{ng} / \mathrm{ml} \mathrm{IGF-1} \mathrm{for}$ an additional $18 \mathrm{~h}$. Neither U0126 (an ERK inhibitor, $10 \mu \mathrm{M}$ ) nor SB203580 (a p38 kinase inhibitor, $10 \mu \mathrm{M}$ ) suppressed GST $\alpha$ protein induction (Fig. 6C). Moreover, SP600125, a selective JNK inhibitor, failed to block GST $\alpha$ induction (Fig. $6 \mathrm{C})$. These data show that none of the MAP kinase pathways is responsible for the induction of GST $\alpha$ by IGF- 1 in IGF-IRoverexpressed hepatoma cells.

Increase in Doxorubicin Sensitivity by Blocking of IGF-IR and PI3 Kinase. To finally test whether the activities of IGF-IR and PI3-kinase pathways are associated with the acquisition of doxorubicin resistance in IGF-IR-H4IIE cells, we determined the doxorubicin cytotoxicity after exposure of cells to IGF-IR-neutralizing antibody and LY294002. Blocking of either IGF-IR or PI3-kinase significantly enhanced doxorubicin-induced cell death in IGF-IR-H4IIE cells (Fig. 7, A and B).

\section{Discussion}

The parenchymal cells of the liver synthesize and secrete IGF-1 and IGF-2, and these secreted IGFs are believed to be participated in postnatal growth. The expression of IGF-IR is very low in adult hepatocytes, whereas its expression is obvious in Kupffer and stellate cells, which suggests that hepatocytes respond poorly to IGFs (Caro et al., 1988). However, a growing body of evidence indicates that IGF-IR expression is increased in the human cirrhotic liver, liver cancer, and HBx-infected hepatoma cells compared with normal adult liver cells (Caro et al., 1988; Kim et al., 1996; Scharf et al., 1998). Moreover, antisense IGF-1 gene therapy may be useful for preventing hepatoma progression (Lafarge-Frayssinet et al., 2002). Recently, it was shown that blocking IGF-IR enhances chemo- and radiotherapy responses and inhibits tumor growth (Min et al., 2005). Hence, IGF signaling seems to be involved both in the pathological progress of hepatoma and in the acquisition of chemotherapy resistance.

In the present study, we show for the first time that IGF1-mediated GST $\alpha$ expression is potentiated in hepatoma cells overexpressing IGF-IR and that enhanced GST $\alpha$ expression in IGF-IR-overexpressing hepatoma cells coincides with a reduced cytotoxic response to doxorubicin. Anthracycline anticancer agents such as doxorubicin and daunorubicin increase reactive oxygen species in cells, and oxidative stress is known to be correlated with the cytotoxicity of these chemotherapeutic agents (Müller et al., 1998). We also found that a representative antioxidant, $N$-acetylcysteine, efficiently blocked doxorubicin-induced cytotoxicity in GFP-H4IIE cells. The induction of GST family protein is a protective adaptive response to oxidative stress (Bergelson et al., 1994). GST functions as an efficient ROS-removing enzyme in cancer cells, and increases in ROS and subsequent apoptosis by doxorubicin were reduced to control levels by GST overexpressing H9C2 cells (L'Ecuyer et al., 2004). In this study, resistance to doxorubicin cytotoxicity in IGF-IR-H4IIE cells was completely reversed by a chemical inhibitor of GST, ethacrynic acid. These results provide evidence that enhanced GST $\alpha$ expression in IR-HCCs by IGF-1 is associated with hepatoma resistance to chemotherapy. 
A number of studies have been conducted on the mechanistic basis of the phase II enzyme induction by monofunctional and bifunctional inducers. Monofunctional inducers transcriptionally activate the expressions of GST $\alpha$ genes through ARE, whereas bifunctional inducers act through both XRE and ARE (Prochaska et al., 1985; Wattenberg, 1985). Moreover, Nrf2 binding to ARE plays a critical role in the induction of phase II detoxifying enzymes, and a lack of Nrf2/ARE activation increases sensitivity to xenobiotics (Enomoto et al., 2001; McMahon et al., 2001). In the present study, we found that IGF-1 failed to stimulate the nuclear translocation of Nrf2 in IR-HCCs. This implies that different

\section{A}

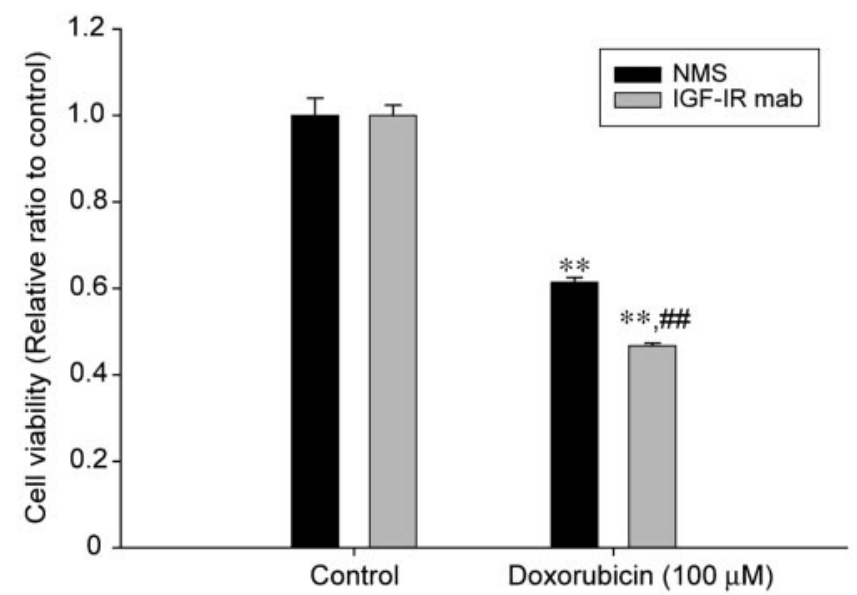

B

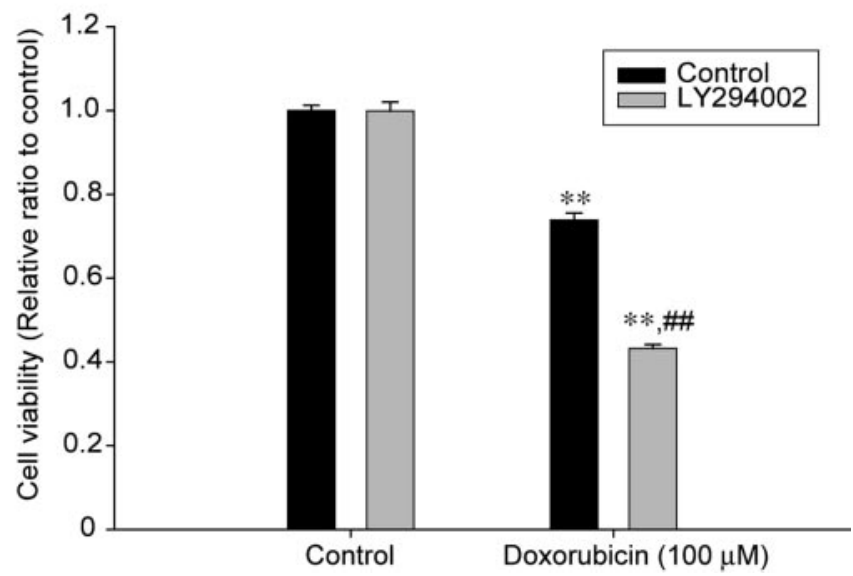

Fig. 7. Increase in doxorubicin sensitivity by blocking of IGF-IR and PI3-kinase. A, effect of IGF-IR neutralizing antibody on doxorubicin cytotoxicity in IGF-IR-H4IIE cells. After incubation of GFP-H4IIE and IGF-IR-H4IIE cells with IGF-IR neutralizing monoclonal antibody (IGF-IR mAb, $1.5 \mu \mathrm{g} / \mathrm{ml}$ ) or normal mouse serum (NMS, $1.5 \mu \mathrm{g} / \mathrm{ml}$ ) for $24 \mathrm{~h}$, both of the cells were exposed to $100 \mu \mathrm{M}$ doxorubicin for $24 \mathrm{~h}$. Cell viabilities were determined using MTT assays. Data represent means \pm S.D. of eight separate samples (significant versus the control: $* *, p<$ 0.01 ; significant versus cell viability in NMS-pretreated doxorubicin group of IGF-IR-H4IIE cells: \#\#, $p<0.01$ ). B, effect of LY294002 on doxorubicin cytotoxicity in IGF-IR-H4IIE cells. GFP-H4IIE and IGF-IRH4IIE cells were treated with $100 \mu \mathrm{M}$ doxorubicin for $24 \mathrm{~h}$ in the presence or absence of LY294002. Cell viabilities were determined using MTT assays. Data represent means \pm S.D. of eight separate samples (significant versus the control: **, $p<0.01$; significant versus cell viability in doxorubicin-treated group of IGF-IR-H4IIE cells: \#\#, $p<0.01$ ). mechanisms are involved in the induction of GST $\alpha$ by IGF-1. We demonstrated previously that the chemopreventive agent, oltipraz, activates $\mathrm{C} / \mathrm{EBP} \beta$ and that its binding to the $\mathrm{C} / \mathrm{EBP} / \mathrm{XRE}$ sequence in GSTA2 promoter is required for the induction of GST $\alpha$ by oltipraz (Kang et al., 2003a). It has also been reported that exposure to growth factors, including IGF-1 and serum, cause C/EBP activation (Harris et al., 2001; LaVoie et al., 2004). Thus, we examined whether IGF-1 activates $\mathrm{C} / \mathrm{EBP} \beta$ and whether this activation is involved in IGF-1-inducible GST $\alpha$ expression. Here, we show that the activation of $\mathrm{C} / \mathrm{EBP} \beta$ by IGF- 1 precedes $\mathrm{GST} \alpha$ protein upregulation, which, in combination with gel shift, luciferasereporter gene, and promoter deletion assays, strongly supports the essential role of C/EBP/XRE in GST $\alpha$ induction by IGF-1 in IR-HCCs. The N-terminal transactivation domains of $\mathrm{C} / \mathrm{EBP} \beta$ are known to interact with $\mathrm{CBP} / \mathrm{p} 300$ coactivator, and these interactions are critical for $\mathrm{C} / \mathrm{EBP} \beta$ transactivation (Mink et al., 1997). Thus, C/EBP $\beta$ binding to the C/EBP/ $\mathrm{XRE}$ site would result in its cooperative interaction with $\mathrm{CBP} / \mathrm{p} 300$ coactivator to transactivate the GSTA2 gene. A recent study has revealed that $\mathrm{C} / \mathrm{EBP} \alpha$ acts as a negative regulator that binds to GST-P enhancer 1 sequence and suppresses GST $\pi$ expression in normal rat liver (Ikeda et al., 2006). In the promoter region of GST-P gene, Nrf2 also binds to GPE1 region and activates the transcription of GST-P gene in preneoplastic region and hepatoma (Ikeda et al., $2004)$. In the present study, we showed that $\mathrm{C} / \mathrm{EBP} \beta$ but not $\mathrm{C} / \mathrm{EBP} \alpha$ is essentially required for the IGF-1-induced GST $\alpha$ expression. Moreover, GST $\pi$ is not inducible by IGF-1 in IGF-IR-H4IIE cells. Hence, it seems that distinct C/EBP isoforms differentially contribute to the activation of ARE $(\mathrm{C} / \mathrm{EBP} \alpha)$ - or $\mathrm{XRE}(\mathrm{C} / \mathrm{EBP} \beta)$-mediated induction of $\mathrm{GST}$ enzymes.

A number of transcription factors are phosphorylated by distinct members of the kinase family, and these phosphorylations are triggered by a variety of growth factors (Pessin and Okada, 1999; Vincent and Feldman, 2002). And, in a series of studies, we demonstrated that PI3-kinase is essentially required for the induction of phase II detoxifying enzymes (Kang et al., 2000, 2001, 2003a). Signaling pathways downstream of PI3-kinase affect cell growth, survival, and motility, and IR-HCCs treated with IGF-1 showed transient PI3-kinase activation, which is consistent with previous studies (Cao et al., 2004). Either chemical inhibition or p85 subunit transfection suppressed $\mathrm{C} / \mathrm{EBP} \beta$ activation and GST $\alpha$ expression by IGF-1 in IR-HCCs. Moreover, the inhibition of $\mathrm{C} / \mathrm{EBP} / \mathrm{XRE}$ activation and $\mathrm{GST} \alpha$ up-regulation by blocking PI3-kinase demonstrates the essential role of PI3-kinase in the regulation of IGF-mediated phase II detoxifying-enzyme expression.

We showed that IGF-1 increased the phosphorylation of ERK but not those of p38 MAP kinase or JNK. Extensive studies support the role of ERK activation as a cell proliferation or cancer progression signal (Fang and Richardson, 2005). It also has been reported that ERK is required for the activation of Nrf2/ARE during the induction of phase II detoxifying genes (Yu et al., 1999; Owuor and Kong, 2002). In the present study, we found that U0126, an ERK-specific inhibitor, failed to inhibit GST $\alpha$ expression in IR-HCCs. As evidenced by either chemical inhibitors or by dominant-negative mutants, neither p38 kinase nor JNK was responsible for the induction of GST $\alpha$ by IGF-1 in IR-HCCs. Hence, the 
MAP kinase pathways, including ERK, are unlikely to be involved in IGF-1-inducible $\mathrm{C} / \mathrm{EBP} / \mathrm{XRE}$ activation in IRHCCs.

Taken together, the present study shows that $\mathrm{C} / \mathrm{EBP} \beta$ is activated by IGF-1 in IGF-IR-overexpressing hepatoma cells and that the PI3-kinase pathway plays a critical role in the activation of $\mathrm{C} / \mathrm{EBP} \beta / \mathrm{XRE}$. Our observation that GST $\alpha$ inducibility by IGF-1 is enhanced in IGF-IR-overexpressing hepatoma cells versus normal hepatoma cells has significant implications for the pathological role of IGF-IR up-regulation during liver carcinogenesis. Recently, evidence has been accumulated that IGF-IR is a promising target for cancer therapy. Increased expression of IGF-IR is found in a variety of tumors, which is correlated with reduced survival, metastasis development and tumor dedifferentiation (Scharf and Braulke, 2003). Although fully differentiated hepatocytes contain few IGF-IRs (McElduff et al., 1988), IGF-IR is frequently overexpressed in HCC (Tsai et al., 1988; Scharf et al., 2001). This may be associated with the aggressive characteristics of HCC, because binding of IGFs to the IGF-IR results in the uncontrolled proliferation of cancer cells through either stimulating cell cycle progression or preventing apoptosis. Hence, IGF-IR is believed to be an attractive therapeutic target for several cancers, including HCC. In fact, IGF-IRblocking antibodies or selective inhibitors to block IGF-IR tyrosine kinase activity have been introduced as potential chemotherapeutic agents (Scotlandi et al., 1998; Höpfner et al., 2006). In this study, we suggest that chemoresistance to doxorubicin in IGF-IR-overexpressed hepatoma is in part related with the induction of GST $\alpha$. Thus, IGF-IR-targeting therapy would be effective to enhance chemotherapeutic activities of anthracyclines.

\section{References}

Bae YS, Kang SW, Seo MS, Baines IC, Tekle E, Chock PB, and Rhee SG (1997) Epidermal growth factor (EGF)-induced generation of hydrogen peroxide. Role in EGF receptor-mediated tyrosine phosphorylation. $J$ Biol Chem 272:217-221.

Bergelson S, Pinkus R, and Daniel V (1994) Induction of AP-1 (Fos/Jun) by chemical agents mediates activation of glutathione $\mathrm{S}$-transferase and quinone reductase gene expression. Oncogene 9:565-571.

Cao WM, Murao K, Imachi H, Yu X, Dobashi H, Yoshida K, Muraoka T, Kotsuna N, Nagao S, Wong NC, et al. (2004) Insulin-like growth factor-I regulation of hepatic scavenger receptor class BI. Endocrinology 145:5540-5547.

Caro JF, Poulos J, Ittoop O, Pories WJ, Flickinger EG, and Sinha MK (1988) Insulin-like growth factor I binding in hepatocytes from human liver, human hepatoma, and normal, regenerating, and fetal rat liver. J Clin Invest 81:976-981.

Cheng JZ, Singhal SS, Sharma A, Saini M, Yang Y, Awasthi S, Zimniak P, and Awasthi YC (2001) Transfection of mGSTA4 in HL-60 cells protects against 4-hydroxynonenal-induced apoptosis by inhibiting JNK-mediated signaling. Arch Biochem Biophys 392:197-207.

Cho MK and Kim SG (2003) Hepatocyte growth factor activates CCAAT enhancer binding protein and cell replication via PI3-kinase pathway. Hepatology 37:686695.

Dupont J and Le Roith D (2001) Insulin-like growth factor 1 and oestradiol promote cell proliferation of MCF-7 breast cancer cells: new insights into their synergistic effects. Mol Pathol 54:149-154

Enomoto A, Itoh K, Nagayoshi E, Haruta J, Kimura T, O’Connor T, Harada T, and Yamamoto M (2001) High sensitivity of Nrf2 knockout mice to acetaminophen hepatotoxicity associated with decreased expression of ARE-regulated drug metabolizing enzymes and antioxidant genes. Toxicol Sci 59:169-177.

Fang JY and Richardson BC (2005) The MAP kinase signaling pathways and colorectal cancer. Lancet Oncol 6:322-327.

Harris VK, Kagan BL, Ray R, Coticchia CM, Liaudet-Coopman ED, Wellstein A, and Tate Riegel A (2001) Serum induction of the fibroblast growth factor-binding protein (FGF-BP) is mediated through ERK and p38 MAP kinase activation and C/EBP-regulated transcription. Oncogene 20:1730-1738.

Hayes JD and Pulford DJ (1995) The glutathione S-transferase supergene family: Regulation of GST and the contribution of the isoenzymes to cancer chemoprotection and drug resistance. Crit Rev Biochem Mol Biol 30:445-600.

Höpfner M, Huether A, Sutter AP, Baradari V, Schuppan D, and Scherubl H (2006) Blockade of IGF-1 receptor tyrosine kinase has antineoplastic effects in hepatocellular carcinoma cells. Biochem Pharmacol 71:1435-1448.

Huang HC, Nguyen T, and Pickett CB (2000) Regulation of the antioxidant response element by protein kinase C-mediated phosphorylation of NF-E2-related factor 2. Proc Natl Acad Sci U S A 97:12475-12480.
Ikeda H, Nishi S, and Sakai M (2004) Transcription factor Nrf2/MafK regulates rat placental glutathione S-transferase gene during hepatocarcinogenesis. Biochem $J$ 380:515-521.

Ikeda H, Omoteyama K, Yoshida K, Nishi S, and Sakai M (2006) CCAAT enhancerbinding protein alpha suppresses the rat placental glutathione S-transferase gene in normal liver. J Biol Chem 281:6734-6741.

Kang KW, Ryu JH, and Kim SG (2000) The essential role of phosphatidylinositol 3 -kinase and of p38 mitogen-activated protein kinase activation in the antioxidant response element-mediated rGSTA2 induction by decreased glutathione in H4IIE hepatoma cells. Mol Pharmacol 58:1017-1025.

Kang KW, Cho MK, Lee CH, and Kim SG (2001) Activation of phosphatidylinositol 3-kinase and Akt by tert-butylhydroquinone is responsible for antioxidant response element-mediated rGSTA2 induction in H4IIE cells. Mol Pharmacol 59: 1147-1156.

Kang KW, Choi SH, and Kim SG (2002a) Peroxynitrite activates NF-E2-related factor 2/antioxidant response element through the pathway of phosphatidylinositol 3-kinase: the role of nitric oxide synthase in rat glutathione S-transferase A2 induction. Nitric Oxide 7:244-253.

Kang KW, Lee SJ, Park JW, and Kim SG (2002b) Phosphatidylinositol 3-kinase regulates nuclear translocation of NF-E2-related factor 2 through actin rearrangement in response to oxidative stress. Mol Pharmacol 62:1001-1010.

Kang KW, Cho IJ, Lee CH, and Kim SG (2003a) Essential role of phosphatidylinositol 3-kinase-dependent CCAAT/enhancer binding protein beta activation in the induction of glutathione S-transferase by oltipraz. J Natl Cancer Inst 95:53-66.

Kang KW, Park EY, and Kim SG (2003b) Activation of CCAAT/enhancer-binding protein beta by 2 '-amino- 3 '-methoxyflavone (PD98059) leads to the induction of glutathione S-transferase A2. Carcinogenesis 24:475-482.

Kensler TW, Egner PA, Dolan PM, Groopman JD, and Roebuck BD (1987) Mechanism of protection against aflatoxin tumorigenicity in rats fed 5-(2-pyrazinyl)-4 methyl-1,2-dithiol-3-thione (oltipraz) and related 1,2-dithiol-3-thiones and 1,2 dithiol-3-ones. Cancer Res 47:4271-4277.

Kim SG, Nam SY, Kim JH, Cho CK, and Yoo SY (1997) Enhancement of radiationinducible hepatic glutathione S-transferase Ya1, Yb1, Yb2, Yc1, and Yc2 expression by oltipraz: Possible role in radioprotection. Mol Pharmacol 51:225-233.

Kim SO, Park JG, and Lee YI (1996) Increased expression of the insulin-like growth factor I (IGF-I) receptor gene in hepatocellular carcinoma cell lines: implications of IGF-I receptor gene activation by hepatitis B virus X gene product. Cancer Res 56:3831-3836.

L'Ecuyer T, Allebban Z, Thomas R, and Vander Heide R (2004) Glutathione Stransferase overexpression protects against anthracycline-induced $\mathrm{H} 9 \mathrm{C} 2$ cell death. Am J Physiol Heart Circ Physiol 286:H2057-H2064.

Lafarge-Frayssinet C, Martin C, Van Binh PN, Achard-Ellouk S, Duc HT, Frayssinet C, Cardoso G, Desauty G, Warnet JM, Brechot C, et al. (2002) Adenovirusmediated anti insulin-like growth factor I gene transfer for the treatment of hepatocellular carcinoma. Anticancer Res 22:3895-3904.

LaVoie HA, Singh D, and Hui YY (2004) Concerted regulation of the porcine steroidogenic acute regulatory protein gene promoter activity by follicle-stimulating hormone and insulin-like growth factor I in granulosa cells involves GATA-4 and CCAAT/enhancer binding protein beta. Endocrinology 145:3122-3134.

Lee SJ and Kim SG (2006) Role of p90 ribosomal S6-kinase-1 in oltipraz-induced specific phosphorylation of CCAAT/enhancer binding protein-beta for GSTA2 gene transactivation. Mol Pharmacol 69:385-396.

Liu J, Chen H, Miller DS, Saavedra JE, Keefer LK, Johnson DR, Klaassen CD, and Waalkes MP (2001) Overexpression of glutathione S-transferase II and multidrug resistance transport proteins is associated with acquired tolerance to inorganic arsenic. Mol Pharmacol 60:302-309.

McElduff A, Poronnik P, and Baxter RC (1988) A comparison of the insulin and insulin-like growth factor I receptors from rat brain and liver. Endocrinology 122:1933-1939.

McMahon M, Itoh K, Yamamoto M, Chanas SA, Henderson CJ, McLellan LI, Wolf CR, Cavin C, and Hayes JD (2001) The Cap'n'Collar basic leucine zipper transcription factor Nrf2 (NF-E2 p45-related factor 2) controls both constitutive and inducible expression of intestinal detoxification and glutathione biosynthetic enzymes. Cancer Res 61:3299-3307.

Min Y, Adachi Y, Yamamoto H, Imsumran A, Arimura Y, Endo T, Hinoda Y, Lee CT Nadaf S, Carbone DP, et al. (2005) Insulin-like growth factor I receptor blockade enhances chemotherapy and radiation responses and inhibits tumour growth in human gastric cancer xenografts. Gut 54:591-600.

Mink S, Haenig B, and Klempnauer KH (1997) Interaction and functional collaboration of p300 and C/EBP. Mol Cell Biol 17:6609-6617.

Müller I, Niethammer D, and Bruchelt G (1998) Anthracycline-derived chemotherapeutics in apoptosis and free radical cytotoxicity. Int J Mol Med 1:491-494.

Owuor ED and Kong AN (2002) Antioxidants and oxidants regulated signal trans duction pathways. Biochem Pharmacol 64:765-770.

Pessin JE and Okada S (1999) Insulin and EGF receptors integrate the Ras and Rap signaling pathways. Endocr J 46 (Suppl):S11-S16.

Pietrzkowski Z, Mulholland G, Gomella L, Jameson BA, Wernicke D, and Baserga R (1993) Inhibition of growth of prostatic cancer cell lines by peptide analogues of insulin-like growth factor 1. Cancer Res 53:1102-1106.

Pinkus R, Weiner LM, and Daniel V (1996) Role of oxidants and antioxidants in the induction of AP-1, NF- $\kappa \mathrm{B}$, and glutathione S-transferase gene expression. J Biol Chem 271:13422-13429.

Prochaska HJ, De Long MJ, and Talalay P (1985) On the mechanisms of induction of cancer-protective enzymes: A unifying proposal. Proc Natl Acad Sci U S A 82:8232-8236.

Scharf JG and Braulke T (2003) The role of the IGF axis in hepatocarcinogenesis. Horm Metab Res 35:685-693.

Scharf JG, Dombrowski F, and Ramadori G (2001) The IGF axis and hepatocarcinogenesis. Mol Pathol 54:138-144.

Scharf JG, Schmidt-Sandte W, Pahernik SA, Ramadori G, Braulke T, and Hartmann 
$\mathrm{H}$ (1998) Characterization of the insulin-like growth factor axis in a human hepatoma cell line (PLC). Carcinogenesis 19:2121-2128.

Schreiber E, Harshman K, Kemler I, Malipiero U, Schaffner W, and Fontana A (1990) Astrocytes and glioblastoma cells express novel octamer-DNA binding proteins distinct from the ubiquitous Oct-1 and B cell type Oct-2 proteins. Nucleic Acids Res 18:5495-5503.

Scotlandi K, Benini S, Nanni P, Lollini PL, Nicoletti G, Landuzzi L, Serra M, Manara MC, Picci P, and Baldini N (1998) Blockage of insulin-like growth factor I receptor inhibits the growth of Ewing's sarcoma in athymic mice. Cancer Res 58:41274131

Sundaresan M, Yu ZX, Ferrans VJ, Irani K, and Finkel T (1995) Requirement for generation of $\mathrm{H}_{2} \mathrm{O}_{2}$ for platelet-derived growth factor signal transduction. Science 270:296-299

Tsai TF, Yauk YK, and Chou CK (1988) Evidence of autocrine regulation in human hepatoma cell lines. Biochem Biophys Res Commun 153:39-45.

Tsang WP, Chau SP, Kong SK, Fung KP, and Kwok TT (2003) Reactive oxygen species mediate doxorubicin induced p53-independent apoptosis. Life Sci 73:20472058.
Vincent AM and Feldman EL (2002) Control of cell survival by IGF signaling pathways. Growth Horm IGF Res 12:193-197.

Wattenberg LW (1985) Chemoprevention of cancer. Cancer Res 45:1-8.

Yamaguchi K, Carr BI, and Nalesnik MA (1995) Concomitant and isolated expression of TGF-alpha and EGF-R in human hepatoma cells supports the hypothesis of autocrine, paracrine and endocrine growth of human hepatoma. J Surg Oncol 58:240-245.

Yu R, Lei W, Mandlekar S, Weber MJ, Der CJ, Wu J, and Kong ANT (1999) Role of a mitogen-activated protein kinase pathway in the induction of phase II detoxifying enzymes by chemicals. $J$ Biol Chem 274:27545-27552.

Zipper LM and Mulcahy RT (2000) Inhibition of ERK and p38 MAP kinases inhibits binding of Nrf2 and induction of GCS genes. Biochem Biophys Res Commun 278:484-492.

Address correspondence to: Dr. Keon Wook Kang, College of Pharmacy, Chosun University, 375 Seosuk-dong, Dong-gu, Gwangju 501-759, South Korea; E-mail: kwkang@chosun.ac.kr 